\title{
Therapy with PAMORA (peripherally acting $\mu$-opioid receptor antagonists) drugs in patients receiving palliative care
}

On the basis of scientific sources, opioid-induced constipation concerns approximately $90 \%$ of cancer patients and significantly impairs the quality of life of patients receiving palliative care [1].

Macrogols, lactulose, sennosides, bisacodyl, glycerine suppositories and infusions are most commonly applied methods in the prevention and treatment of constipation in palliative care patients. According to the research conducted in 2018, methylnaltrexone, naloxegol or naldemedine were never used for the treatment in $75 \%$ of hospices [2].

Methylnaltrexone, naloxegol, alvimopan and naldemedine are drugs belonging to peripherally acting-opioid receptor antagonists $\mu$ (PAMORA). There is no evidence showing the difference in the effectiveness between naloxegol and methylnaltrexone. In palliative care patients, more research concerned subcutaneous methylnaltrexone [3]; the data on the effectiveness of naloxegol is limited to patients with opioid-induced constipation where opioids were administered due to non-cancerous pain.

In your overview study published in "Palliative Medicine in Practice" 3/2019 you quote systematic reviews of clinical trials in which naldemedine was assessed as effective and well tolerated by patients and as a suitable choice in the treatment of opioid-induced constipation in patients with cancer and other diseases [4].

According to the systematic review of Cochrane, scientific evidence of moderate quality indicates that naldemedine administered orally for 14 days improves bowel function in patients with cancer and opioid-induced constipation, but simultaneously increases the risk of side effects [5].

There is no new data on the use of naloxone or methylnaltrexone. There is moderate-strength evidence indicating an improvement in bowel function in palliative care patients treated with methylnaltrexone for 14 days, as well as low-strength evidence indicating that such treatment does not cause any side effects. No current research has described the effects of treatment in children.

The quality of the evidence from such research can be described as very low or moderate. A very low quality means that evidence does not prove the therapy safety. In the research quoted there are several inaccuracies, such as an inaccurate description of research methods.

Currently available knowledge is not sufficient enough to draw conclusions and safely implement the therapy with PAMORA drugs in palliative care patients. In individual cases of cancer patients with opioid-induced constipation, in whom therapy with standard drugs has not brought any improvement, the use of PAMORA drugs may be considered.

\section{References}

1. Camilleri M. Opioid-induced constipation: challenges and therapeutic opportunities. Am J Gastroenterol. 2011; 106(5): 835-842.

2. Sera L., McPherson M.L. Management of Opioid-Induced Constipation in Hospice Patients. Am J Hosp Palliat Care. 2018; 35(2): 330-335.

3. Thomas J., Karver S., Cooney G.A. et al. Methylnaltrexone for opioid-induced constipation in advanced illness. N Engl J Med. 2008; 358: 2332-2344.

4. Leppert W. The role of naldemedine in the treatment of patients with opioid-induced constipation. Palliat Med Pract. 2019; 13 (3): 113-128.

5. Candy B., Jones L., Vickerstaff V., Larkin P.J., Stone P. Mu-opioid antagonists for opioid-induced bowel dysfunction in people with cancer and people receiving palliative care. Cochrane Database of Systematic Reviews. 2018, 6: CD006332. DOI: 10.1002/14651858. CD006332.pub3.

\section{Address for correspondence:}

Aleksandra Masłowska

Franciszek Raszeja Municipal Hospital in Poznań; ul. Mickiewicza 2, Poznań; e-mail: aleksandra.maslowka94@gmail.com 


\section{Wojciech Leppert}

Laboratory of Quality of Life Research, Poznan University of Medical Sciences, Poznan, Poland

Editor-in-Chief "Palliative Medicine in Practice"

\section{Comment}

Dear Doctor Gabriela Picco, thank you very much for your letter and for your critical view of the role of PAMORA drugs in the treatment of palliative care patients with opioid-induced constipation (OIC) [1]. The author's thesis is obviously correct that OIC, and more broadly, opioid-induced bowel dysfunction (OIBD) is a significant clinical problem and numerous symptoms, particularly those associated with OIC, cause significant deterioration in the quality of life of patients and, indirectly, their families.

The treatment with PAMORA, as it has been correctly stated in the list, can be considered when standard laxatives - which constitute the first line of management used both in prophylaxis and the treatment of OIBD and OIC symptoms - are ineffective. It should be mentioned that drugs belonging to PAMORA show some differences, e.g. nalemedine exhibits non-competitive antagonistic effects, slower bonding and dissociation from opioid $\mu$ receptors, when compared to naloxone and naloxegol. Moreover, naldemedine demonstrates less severe diarrhoea when compared to the above-mentioned drugs [2]. Alvimopan has been approved only for the short-term treatment of postoperative bowel obstruction due to side effects, and it is not used in the treatment of OIC.

The American Society of Gastroenterology recommends the application of naldemedine in patients with OIC and nonresponse to laxatives (strong recommendation, high-quality evidence), naloxegol (strong recommendation, moderate-quality evidence) and methylnaltrexone (conditional recommendation, moderate-quality evidence) [3]. Similarly, ESMO also recommends the use of PAMORA and a combination of opioid with naloxone in the treatment of patients with OIC, non-responding to laxatives (preferred osmotic drugs and rectal nerve plexus stimulants; psyllium sand plantain and other drugs increasing stool volume not recommended) (IIB) [4].

Other therapeutic options should be mentioned here, particularly the use of opioids (administered orally) with a lower risk of causing OIC: a combination of oxycodone with naloxone or self-administered prolonged-release naloxone (the latter is currently undergoing clinical trials [5]. Another solution, especially in patients with neuropathic pain, is tapentadol, which provides the so-called $\mu$-sparing effect, associated with limited effect of the drug on $\mu$-receptors and simultaneous activation of the descending pain inhibitory system (noradrenergic effect). Among the older drugs, tramadol (mainly applied in patients with moderate pain) should be mentioned, which also has a slight affinity for the opiodic receptor $\mu$. The context of many factors influencing stool constipation in palliative care patients as well as a significant role of education and non-pharmacological measures cannot be ignored. New prokinetic drugs are also used, although there are no clear recommendations in this respect.

Further PAMORA clinical trials will enable us to assess the effectiveness and safety of application of this group of drugs in patients receiving palliative care. Some caution is dictated by the reports concerning individual patients in whom the use of methylnaltrexone resulted in perforation of the gastrointestinal tract (in some cases, leading to death), however, it remains unclear to what extent this severe side effect was associated with improper use of the drug and how important role was played by gastrointestinal comorbidities. In the clinical trials conducted so far, concerning naloxegol and naldemedine, such serious side effects have not been observed.

Therefore, PAMORA are treated as one of available options for the treatment of OIC, in patients non-responding to standard laxatives. Other therapies should be taken into account, as well as PAMORA treatment costs. However, the costs of burdening patients and caregivers with negative effects of OIBD (also the costs of treatment), as well as the possibility to influence OIBD patomechanism and avoid the need for performing such invasive procedures as rectal infusions or manual interventions necessary in case of fecal impaction, should be considered. Undoubtedly, the awareness of medical staff, patients and caregivers, together with early prophylaxis and accurate clinical evaluation, play a key role in the effective prevention and treatment of palliative care patients with OIBD symptoms.

\section{References}

1. Picco G. Terapia lekami z grupy PAMORA (Peripherally acting $\mu$-opioid receptor antagonists) $\mathrm{u}$ chorych w opiece paliatywnej. Palliat Med Pract. 2020; 14(1).

2. Kanemasa T., Koike K., Takase K. et al. Pharmacological Profile of Naldemedine, a Peripherally Acting $\mu$-Opioid Re- 
ceptor Antagonist: Comparison with Naloxone and Naloxegol. J Pharmacol Exp Ther. 2020. pii: jpet.119.264515. doi: 10.1124/jpet.119.264515. [Epub ahead of print]

3. Crockett S.D., Greer K.B., Heidelbaugh J.J. et al.; on behalf of American Gastroenterological Association Institute Clinical Guidelines Committee American Gastroenterological Association Institute Guideline on the Medical Management of Opioid-Induced Constipation. Gastroenterology. 2019; 156: 218-226.
4. Larkin P.J., Cherny N.I., La Carpia D. et al., on behalf of the ESMO Guidelines Committee. Diagnosis, assessment and management of constipation in advanced cancer: ESMO Clinical Practice Guidelines. Ann Oncol. 2018; 29(suppl. 4): iv94-iv108.

5. Leppert W., Zajaczkowska R., Wordliczek J. The role of oxycodone/naloxone in the management of patients with pain and opioid-induced constipation. Expert Opin Pharmacother. 2019; 20: 511-522 


\section{Terapia lekami z grupy PAMORA (Peripherally acting $\mu$-opioid receptor antagonists) u chorych w opiece paliatywnej}

Artykuł jest tłumaczeniem pracy: Picco G., Masłowska A., Therapy with PAMORA (peripherally acting $\mu$-opioid receptor antagonists) drugs in patients receiving palliative care. Palliat. Med. Pract. 2020 tom 14, nr 1: 68.

Należy cytować wersję pierwotną.

Piśmiennictwo znajduje się na stronach 68.

Źródła naukowe donoszą, że zaparcia wywołane opioidami dotyczą około $90 \%$ chorych na nowotwory i znacznie pogarszają jakość życia pacjentów w opiece paliatywnej [1]. Makrogole, laktuloza, sennozydy, bisacodyl, czopki glicerynowe i wlewy są najczęściej stosowane w profilaktyce i leczeniu zaparć u pacjentów objętych opieką paliatywną. Według badań przeprowadzonych w 2018 roku, w 75\% hospicjów nigdy nie stosowano leczenia metylnaltreksonem, naloksegolem ani naldemedyną [2].

Metylnaltrekson, naloksegol, alvimopan i naldemedyna to leki z grupy antagonistów obwodowych receptorów opioidowych $\mu$ (PAMORA, peripherally acting $\mu$-opioid receptor antagonists). Brak dowodów na różnicę w skuteczności naloksegolu i metylnaltreksonu. U chorych objętych opieką paliatywną więcej badań dotyczyło metylnaltreksonu podawanego drogą podskórną [3], a dane o skuteczności naloksegolu ograniczone są do pacjentów z zaparciem wywołanym opioidami podawanymi z powodu bólu nienowotworowego.

W pracy przeglądowej opublikowanej w „Palliative Medicine in Practice" 3/2019 autor cytuje przeglądy systematyczne badań klinicznych, w których naldemedynę oceniono, jako lek skuteczny i dobrze tolerowany przez pacjentów oraz jako odpowiedni wybór w leczeniu zaparć wywołanych opioidami u chorych na nowotwory i z innymi schorzeniami [4].
Według przeglądu systematycznego Cochrane umiarkowanej jakości dowody naukowe wskazują, że naldemedyna podawana drogą doustną przez okres $14 \mathrm{dni}$ poprawia czynność jelit u chorych na nowotwory i z zaparciami wywołanymi przez opioidy, lecz jednocześnie zwiększa ryzyko wystąpienia działań niepożądanych [5].

Brak nowych danych dotyczących stosowania naloksonu czy metylnaltreksonu. Istnieją dowody o umiarkowanej sile, wskazujące na poprawę czynności jelit u pacjentów objętych opieką paliatywną leczonych metylnaltreksonem przez okres 14 dni i dowody o niskiej sile wskazujące, że leczenie takie nie powoduje działań niepożądanych. W żadnym aktualnym badaniu nie opisano efektów leczenia u dzieci.

Jakość dowodów pochodzących z tych badań można określić jako bardzo niską lub umiarkowaną. Bardzo niska jakość oznacza, że dowody nie wykazują bezpieczeństwa stosowania terapii. W cytowanych badaniach można zauważyć kilka nieścisłości, jak choćby niedokładny opis metod badawczych.

Obecnie dostępna wiedza nie jest wystarczająca, aby wyciągnąć $z$ nich wnioski i bezpiecznie wdrażać terapię lekami z grupy PAMORA u pacjentów objętych opieką paliatywną. W przypadkach indywidualnych chorych na nowotwory z zaparciem wywołanym opioidami, u których terapia standardowymi lekami nie przyniosła poprawy można rozważyć zastosowanie leku z grupy PAMORA.

\section{Adres do korespondencji:}

Aleksandra Masłowska

Szpital Miejski im. Franciszka Raszei w Poznaniu; ul. Mickiewicza 2, Poznań; e-mail: aleksandra.maslowka94@gmail.com 


\section{Komentarz}

Komentarz jest tłumaczeniem: Wojciech Leppert, Comment. Palliat. Med. Pract. 2020 tom 14, nr 1: 69-70.

Należy cytować wersję pierwotną.

Piśmiennictwo znajduje się na stronach 69-70.

Szanowna Pani Doktor Gabriela Picco, bardzo dziękuję za list i za krytyczne spojrzenie na rolę leków z grupy PAMORA w leczeniu chorych objętych opieką paliatywną i zaparciem stolca wywołanym opioidami (OIC, opioid-induced constipation) [1]. Należy zgodzić się z tezą Autorki, że OIC, a szerzej ujmując, poopioidowe zaburzenia jelitowe (OIBD, opioid-induced bowel dysfunction) stanowią istotny problem kliniczny, a liczne objawy, zwłaszcza związane z OIC, powodują znaczne pogorszenie jakości życia pacjentów i pośrednio rodzin.

Leczenie PAMORA, jak slusznie stwierdzono w liście, można rozważać, kiedy tradycyjne leki przeczyszczające, które stanowią pierwszą linię postępowania, zarówno profilaktycznego, jak i leczenia objawów OIBD i OIC, są nieskuteczne. Warto wspomnieć, że leki z grupy PAMORA cechują pewne różnice, na przykład nalemedyna wykazuje niekompetycyjne działanie antagonistyczne, wolniejsze łączenie i dyscocjację z receptorów opioidowych $\mu$, w porównaniu $z$ naloksonem i naloksegolem. Ponadto, naldemedyna wykazuje mniej nasiloną biegunkę w porównaniu ze wspomnianymi lekami [2]. Alvimopan został zarejestrowany wyłacznie do krótkotrwałego leczenia pooperacyjnej niedrożności jelit ze względu na działania niepożądane i nie jest stosowany w leczeniu OIC.

Amerykańskie Towarzystwo Gastroenterologiczne zaleca stosowanie naldemedyny u chorych z OIC i brakiem odpowiedzi na leki przeczyszczające (silna rekomendacja, wysoka jakość dowodów), naloksegolu (silna rekomendacja, umiarkowana jakość dowodów), a także metylnaltreksonu (warunkowa rekomendacja, umiarkowana jakość dowodów) [3]. Podobnie ESMO zaleca stosowanie PAMORA i połączenia opioidu z naloksonem, jako leczenie u chorych z OIC nieodpowiadającym na leki przeczyszczające (preferowane leki osmotyczne i pobudzające sploty nerwowe jelita grubego, nie zalecane babka płesznik i inne leki zwiększające objętość stolca) (IIB) [4].

Warto wspomnieć o innych możliwościach terapeutycznych, zwłaszcza zastosowania opioidów o mniejszym ryzyku wywołania OIC: połączenia ok- sykodonu z naloskonem czy samodzielnie stosowanego naloksonu o przedłużonym uwalnianiu (to ostatnie postępowanie obecnie w trakcie badań klinicznych) podawanych drogą doustną [5]. Inne rozwiązanie, zwłaszcza u chorych z bólem neuropatycznym, stanowi tapentadol, zapewniający tak zwany „efekt oszczędzający” receptory $\mu$ ( $\mu$-sparing effect) związany z ograniczonym wpływem leku na receptory $\mu$ i jednocześnie aktywacji układu zstępujacego hamowania bólu (efekt noradrenergiczny). Ze starszych leków warto wymienić tramadol, znajdujący zastosowanie głównie u chorych z bólem o umiarkowanym natężeniu, który cechuje również niewielkie powinowactwo do receptora opiodowego $\mu$. Nie można pominąć kontekstu wielu czynników wpływających na zaparcie stolca u chorych w opiece paliatywnej, a także istotnej roli edukacji i środków niefarmakologicznych. Stosowane są również nowe leki prokinetyczne, choć brak w tym względzie jednoznacznych rekomendacji.

Przyszłe badania kliniczne PAMORA pozwolą ocenić skuteczność i bezpieczństwo stosowania tej grupy leków u chorych w opiece paliatywnej. Pewną ostrożność nakazują doniesienia dotyczące pojedynczych chorych, u których stosowanie metylnaltreksonu spowodowało perforację przewodu pokarmowego (u części prowadzącą do zgonu), jednak pozostaje nie do końca wyjaśnione na ile to ciężkie dzialanie niepożadane było związane z niewłaściwym zastosowaniem leku, a także, na ile istotną rolę odegrały współistniejące choroby przewodu pokarmowego. W dotychczas przeprowadzonych badaniach klinicznych naloksegolu i naldemedyny takich poważnych działań niepożadnych nie obserwowano.

PAMORA stanowią, więc jedną z dostępnych opcji leczenia OIC, u chorych nieodpowiadających na tradycyjne leki przeczyszczające. Należy uwzględnić inne terapie, a także koszty leczenia PAMORA. Warto jednak brać pod uwagę koszty obciążenia chorych i opiekunów negatywnymi skutkami OIBD (również koszty leczenia), a także możliwość wpływu na patomechznizm OIBD i uniknięcie konieczności stosowania 
procedur inwazyjnych, takich jak wlewy doodbytnicze czy interwencje manualne niezbędne w przypadku zaczopowania odbytnicy masami kałowymi. Niewątpliwie świadomość personelu, pacjentów i opieku- nów wraz z wczesną profilatkyką i dokładną oceną kliniczną odgrywają kluczową rolę w skutecznym zapobieganiu i leczeniu chorych z objawami OIBD w opiece paliatywnej. 